\title{
"Somos del campo": Latino and Latina gardeners and farmers in two rural communities of Iowa - a Community Capitals Framework approach
}

\author{
Diego Thompson ${ }^{\mathrm{a}}$
}

Submitted 15 July 2010 / Accepted 12 December 2010 / Published online 11 April 2011

Citation: Thompson, D. (2011, Spring). "Somos del Campo": Latino and Latina gardeners and farmers in two rural communities of Iowa - a Community Capitals Framework approach. Journal of Agriculture, Food Systems, and Community Development, 1(3), 3-18. http://dx.doi.org/10.5304/jafscd.2011.013.001

Copyright (C) 2011 by New Leaf Associates, Inc.

\begin{abstract}
Using the Community Capitals Framework approach, this study describes what makes it possible for Latinos and Latinas to become gardeners and beginning farmers in two rural Iowa communities. Four in-depth interviews were carried out in Denison, Iowa, and four in Marshalltown, Iowa, with Latino and Latina gardeners and beginning farmers participating in community gardening and farming programs. I used participant observation in people's homes and garden plots to understand the meaning of gardening and farming among Latinos. Human, cultural, and social capitals are essential elements in the success of Latino gardeners. The interaction between these three capitals mobilizes other community capitals to improve household well-being. These Latinos bring to their new gardening and farming efforts their previous
\end{abstract}

\footnotetext{
a Doctoral student, Sociology Department, Iowa State University, 409A East Hall, Iowa 50014 USA; diego@,iastate.edu; +1-515-203-1025.

This paper is based on the author's master's thesis at Iowa State University presented in spring 2010, "Somos del campo" Latino/ a gardeners and farmers in two rural communities of Iowa $A$ Community Capitals Framework approach. Available at ProQuest, http://gradworks.umi.com/14/76/1476356.html
}

knowledge of agriculture, fresh food, and how to cook it from their countries of origin and other parts of the U.S. Recommendations center on how to strengthen the most critical community capitals.

\section{Keywords}

Latinos, Latinas, immigrants, community gardens, beginning farmers, Community Capitals

Framework, Iowa

\section{Latinos and the Community Capitals Framework Approach}

Between 1990 and 2000 the Latino population in the U.S. grew $57.9 \%$, and in 2001 Latinos made up $12.5 \%$ of the total population (Díaz \& Guzmán, 2002; Guzmán, 2001). The Hispanic population is projected to more than double between 2000 and 2050 (U.S. Census Bureau, 2009). The growth has been very rapid in the Midwest (Díaz \& Guzmán, 2002), particularly in rural towns with meat-packing plants like Denison and Marshalltown, Iowa. ${ }^{1}$

\footnotetext{
${ }^{1}$ Among Iowa counties in 2009, Crawford (where Denison is located) was tied for first in the proportion of its population $(22 \%)$ that is Hispanic; Marshall County ranks fourth (17\%). (State Data Center of Iowa, 2010).
} 
Labor markets and local enterprises in both towns have been affected by the new immigrants. While early employment was in meat packing, other "invisible" employment developed in the informal sector (Tienda \& Raijman, 2000).

In the middle of the past decade, Latinos in those two towns began participating in farming and gardening programs organized by Iowa State University Extension, the Leopold Center for Sustainable Agriculture, Iowa Valley Community College in Marshalltown (MCC), the National Center for Appropriate Technology (NCAT), and M and M Resource Conservation and Development Council (RC\&D) (serving west-central Iowa) and the Prairie Rivers of Iowa RC\&D (serving central Iowa). Community gardens and a farm incubator opened new opportunities for the social, economic, and cultural integration of Latino immigrants into local agriculture and local food systems.

The Community Capitals Framework (CFF) is a methodology that can help identify elements that facilitate Latino and Latina involvement in these enterprises, to describe the challenges, and to assess the implications that these initiatives have within the Latino community and the larger community. The CCF includes seven types of capital: natural, cultural, human, social, political, financial, and built (Flora \& Flora, 2008). “These capitals can either enhance or detract from one another, and resources can under certain circumstances be transformed from one form of capital to another" (Flora \& Flora, 2008, p. 17). For Latinos participating in these gardening and farming projects, I propose that the different community capitals interact with one another in specific ways (see figure 1).

Description of the capitals involved in Latino and Latina gardening and farming experiences will illuminate how the different capitals are configured in each setting and how they interact, facilitating the process by which Latino immigrants can get access to land, cultivate and consume their own fresh food, and perhaps market some of their products.

\section{Human Capital}

In Denison and Marshalltown, Lewis and Tafoya (2008) found that $83 \%$ of 111 Latino participants of rural origin grew up on farms that were operated by their parents or grandparents in their countries of origin (Mexico, El Salvador, and Guatemala). They left their family farms at an average age of 19 years (Lewis \& Tafoya, 2008). Over half the participants became farmworkers, and $83 \%$ had experience with vegetable production as well as with mixed systems of vegetables, grains, and livestock (Lewis \& Tafoya, 2008). Experiences that Latinos bring from their background in agriculture in their countries of origin, from farmworker jobs, and from gardening experience in the U.S., give them skills in diverse types of agricultural production. Ninety-four percent of the participants who participated in the Lewis and Tafoya study in Denison and Marshalltown had performed some
Figure 1. Upward Spiral with the Community Capitals

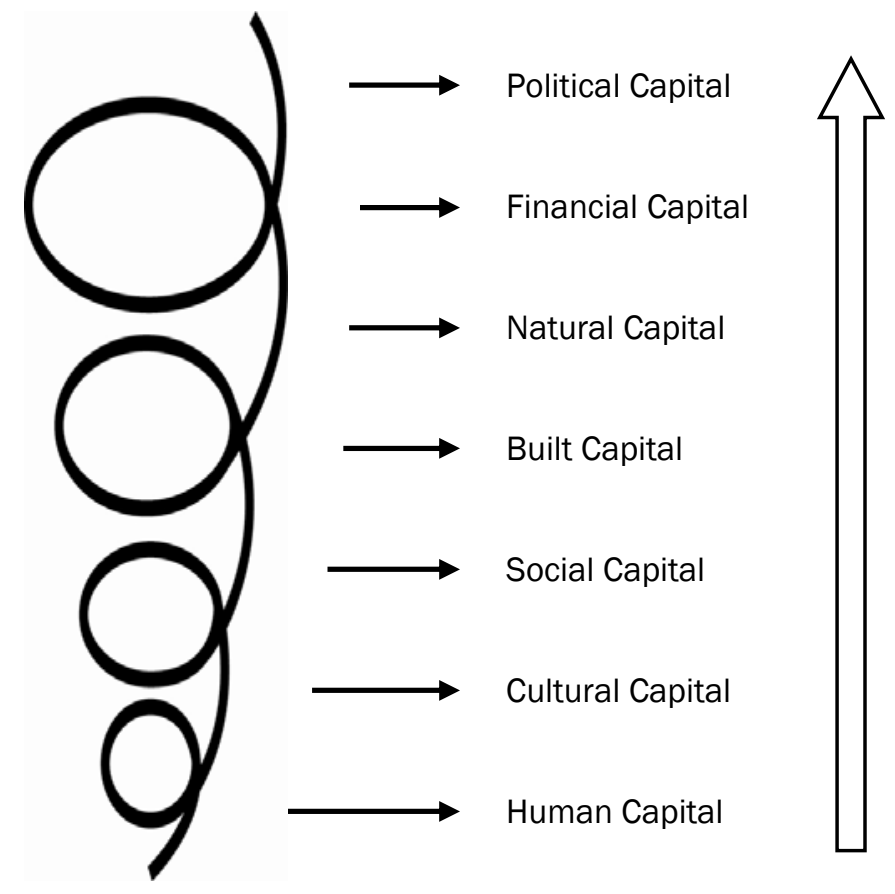


type of fieldwork, including planting, harvesting, weeding, and pruning (Lewis \& Tafoya, 2008). Fifty-two percent had experience in selecting and saving seeds, $60 \%$ had experience in marketing agricultural products, and $24 \%$ had experience in preserving food through drying or canning (Lewis \& Tafoya, 2008).

Several examples from the community gardening literature suggest how community gardens offer spaces for knowledge exchange and education (e.g., Lawson, 2005). In community gardens in Latino New York City neighborhoods, educational activities for and among children not only offer ethnic group members the opportunity to learn from one another about gardening and farming; the gardens also provide a venue for knowledge exchange between groups and with the agencies that support the gardens. These educational activities promote civic agriculture (Kransy \& SaldivarTanaka, 2004; Lyson, 2004). The mobilization of human capital in educational gardening programs can provide spaces for building social capital (Kransy \& Saldivar-Tanaka, 2004; Lawson, 2005).

\section{Cultural Capital}

Cultural capital consists of values and worldview. It is transmitted through the socialization process (Flora \& Flora, 2008). Cultural capital is the way people regard the world surrounding them, which can have both material and nonmaterial implications.

In the Latino community gardens in New York City, gardeners organize many cultural events such as birthdays, Christmas and Halloween celebrations, and weddings, as well as religious activities such as Día de la Cruz, Day of the Dead, and others. According to Kransy and Saldivar-Tanaka (2004), the organization of those events in the open spaces provided by the gardens is more important than the produce derived from that land. As expressed by a staff member of one of those gardens, people want to garden because it gives them a sense of their culture and a sense of strength (Kransy \& Saldivar-Tanaka, 2004). Lewis (2007) describes how Mexican farmers in Iowa perceive their agricultural activities as reconstruc- ting their cultural backgrounds. Similarly, cultural capital among Latino and Latina gardeners and beginning farmers in Denison and Marshalltown may have special meaning that need to be explored.

\section{Social Capital}

Social capital emerges out of networks of more or less "institutionalized relationships of mutual acquaintance and recognition" that provide each member with "collectivity-owned capital" (Bourdieu, 1986, pp. 248-249). In the U.S., community-garden programs historically have tried to reinforce the importance of the social relationships within those enterprises (Lawson, 2005). As Winne (2008) points out, the most important word in "community garden" is community.

In the Latino community gardens in New York City, social activities connected to the gardens are essential elements in motivating the participants (Kransy \& Saldivar-Tanaka, 2004). In addition, Kransy and Saldivar-Tanaka (2004) found that social capital was transformed into political capital such that community development came to be more important than agricultural production.

There are two main types of social capital that are not necessarily mutually exclusive. Bonding social capital is made up of the connections among individuals or groups with similar backgrounds, while bridging social capital involves connections among diverse groups within the community to each other and to groups outside the community (Flora \& Flora, 2008). Bridging social capital in the absence of bonding social capital can create conflicts between different internal groups through the pressures of external groups seeking power (Bourdieu, 1986; Bourdieu \& Passeron, 1977; Flora \& Flora, 2008). Glover (2004) points out that social capital can be both a benefit and a cost, depending upon the position that gardeners occupy within the social networks.

\section{Built and Natural Capitals}

Built capital consists of physical infrastructure, machinery, and tools. In the case of community gardens and farms, that includes irrigation systems, tillage equipment, gardening tools, and fencing. 
Natural capital includes soil quality, water quantity and quality, natural and cultivated biodiversity, and landscapes (Flora \& Flora, 2008). Ability to garden and farm requires access to and control of both these capitals.

These two capitals represent challenges for the sustainability of community gardens and farming areas around the country. The quantity and quality of land and water available to local residents for agricultural production are critical issues of access to natural capital. The land available for gardening within urban areas, in towns, and in their immediate hinterlands depends on historical and political contexts, local authorities, and sometimes even national programs (Hou, Johnson, \& Lawson, 2009; Lawson, 2005). As a consequence, one of the biggest problems faced by many community gardens, as well as farm incubators, is long-term institutional support and continuity of the provision of public land, which is regularly challenged by developers and other private interests. In response to those threats, some gardeners have used resistance strategies. In New York, Latino gardeners have had an active role in modifying the landscapes and building casitas (small houses) for their regular meetings and celebrations. Today, they "contrast sharply with the more uniform and refined aesthetics of institutionalized landscapes, such as the city parks" (Kransy \& Saldivar-Tanaka, 2004, p. 409).

\section{Financial Capital}

Financial capital includes a variety of financial instruments invested to create additional monetary value. Other community capitals can be used to increase financial capital (Flora \& Flora, 2008). In Denison and Marshalltown, a great number of the Latino population and six of the eight gardeners and beginning farmers who participated in this study work in the local meat-packing plants. In recent decades, the meat-packing industry has hired ethnic minorities such as Latinos at lower wages than those of American-born workers who were hired previously (Fink, 1998).

Access to land and capital to purchase inputs represents some of the most important barriers for Latino beginning farmers (Lewis, 2007). Lewis \&
Tafoya (2008) found that in Marshalltown and Denison, $97 \%$ of women and $81 \%$ of men considered access to capital to buy land the greatest barrier to starting farming.

\section{Political Capital}

Political capital is the power to influence the market, state, civil society, and laws (Flora \& Flora, 2008). Political capital is low among new immigrants. They are often invisible (in order to protect themselves or family members from deportation) and lack voice in their workplaces and communities. According to Flora \& Flora (2008), political capital is fostered by purposeful organization and development of strategic connections.

Collective gardening and farming experiences can provide opportunities for organizing and gaining more political visibility. In Latino community gardens in New York City, gardens are "participatory landscapes" where people consider activism to be one of the most important elements of their participation in gardening (Kransy \& SaldivarTanaka, 2004). Community gardens in this country historically have been used to address different social and political agendas (Allen, 2008; Lawson, 2005). For Latino immigrants, political capital gained through working together and with outside groups in gardens and on farms can strengthen sustainable livelihoods. This can help overcome their vulnerability in terms of political representation and power in rural towns.

\section{Research Methods}

In this study I explore the human capital that Latino gardeners and beginning farmers bring from their countries and from other parts of the U.S., and how that knowledge is enriched through their experiences in community gardens and a beginning farmer program in Iowa.

I examine the ways in which gardening utilizes and recreates cultural capital in the Latino community. I study both positive and negative ways in which social capital can influence Latinos' gardening and farming experiences in Iowa. Gardening may enhance or detract from social relationships among gardeners and with the rest of the community. 
Journal of Agriculture, Food Systems, and Community Development

ISSN: 2152-0801 online

www.AgDevJournal.com

Table 1. Gardeners and beginning farmers interviewed ${ }^{a}$

\begin{tabular}{|c|c|c|c|c|c|}
\hline Names & $\begin{array}{l}\text { City and Country } \\
\text { of Origin }\end{array}$ & Gardening and Farming Programs & $\begin{array}{l}\text { Length of } \\
\text { Participation }\end{array}$ & Age & Gender \\
\hline Oscar & Jalisco, Mexico & $\begin{array}{l}\text { Start Your Own Diversified Farm-MCC- } \\
\text { Marshalltown }\end{array}$ & $1^{\text {st }}$ year & 57 & Male \\
\hline Guillermo & Michoacán, Mexico & $\begin{array}{l}\text { Start Your Own Diversified Farm-MCC- } \\
\text { Marshalltown }\end{array}$ & $1^{\text {st }}$ year & 34 & Male \\
\hline Pablo & Guanajuato, Mexico & Community Garden-MCC- Marshalltown & $4^{\text {th }}$ year & 40 & Male \\
\hline Martín & Guanajuato, Mexico & Community Garden-MCC- Marshalltown & $6^{\text {th }}$ year & 48 & Male \\
\hline Lucía & Guachapán, El Salvador & Denison Community Gardens & $4^{\text {th }}$ year & 32 & Female \\
\hline Ricardo & Campeche, Mexico & Denison Community Gardens & $4^{\text {th }}$ year & 36 & Male \\
\hline Juan & $\begin{array}{l}\text { Quesada Municipality, } \\
\text { Guatemala }\end{array}$ & Denison Community Gardens & $1^{\text {st }}$ year & 49 & Male \\
\hline Raúl & Campeche, Mexico & Denison Community Gardens & 1st year & 40 & Male \\
\hline
\end{tabular}

a I used pseudonyms to assure confidentiality and to protect the identities of the subjects interviewed.

I also analyze how Latinos gain collective access to natural and built capital through their participation in farming and gardening programs and the support of local institutions. I explore how Latinos who participated in the gardens and farm generated the capital necessary to access land and inputs through sources other than sale of production, and I analyze the degree to which financial capital motivates or discourages Latino farmers and gardeners. I examine the degree to which growing high-quality food and participating in local agricultural enterprises give immigrant gardeners and farmers more voice (political capital) in their local community and in the programs designed to serve them.

Participant observation allowed me to participate as intimately as possible in the experience of the subjects studied (Denzin, 1970). As I gathered my data, I attempted to be part of the diverse processes of farming and gardening in the two communities, and, as Denzin proposes, to "be part of the day-to-day experiences" (1989, p. 156).

I used purposive sampling to ensure different backgrounds in gardening and farming, different nationalities (Mexican, Salvadoran, and Guatemalan), different ages (from 32 to 57 years), and male and female gardeners (see table 1).
I interviewed eight of the 28 Latino and Latina immigrant gardeners and beginning farmers who participated in two different community gardens and in small-scale incubator plots in the two towns of Denison and Marshalltown, Iowa. In Marshalltown, two Latino farmers were chosen from the $\mathrm{COMIDA}^{2}$ program and the beginning farmer course it offers, Start Your Own Diversified Farm, ${ }^{3}$ located at Iowa Valley Community College in Marshalltown (hereafter referred to as Marshalltown Community College, or MCC). I was acquainted with these two participants because I was one of the organizers and interpreters for the course. Two gardeners from the community gardens at MCC were also selected to participate. In Denison, four participants were chosen from among the Latino gardeners participating in Denison Community Gardens based on information provided by other organizers of that community garden and what I knew about them as an organizer myself.

Case studies and participant observation provide data for cross-sectional and longitudinal analysis (Neuman, 2003), as data were collected before, during, and after the farming seasons of 2008 and 2009.

\footnotetext{
${ }^{2}$ County of Marshall Investing in Diversified Agriculture

${ }^{3}$ In Spanish, Comience su propia granja diversa.
} 
Table 2. Numbers of times that the participants mentioned indicators of each of the community capitals during the interviews

\begin{tabular}{|c|c|c|c|c|c|c|c|}
\hline Gardeners & $\begin{array}{l}\text { Human } \\
\text { Capital }\end{array}$ & $\begin{array}{l}\text { Cultural } \\
\text { Capital }\end{array}$ & $\begin{array}{l}\text { Social } \\
\text { Capital }\end{array}$ & $\begin{array}{l}\text { Natural } \\
\text { Capital }\end{array}$ & $\begin{array}{l}\text { Built } \\
\text { Capital }\end{array}$ & $\begin{array}{c}\text { Financial } \\
\text { Capital }\end{array}$ & $\begin{array}{l}\text { Political } \\
\text { Capital }\end{array}$ \\
\hline Oscar & 5 & 4 & 3 & 4 & 3 & 2 & 1 \\
\hline Guillermo & 10 & 2 & 8 & 3 & 1 & 1 & 1 \\
\hline Pablo & 8 & 3 & 9 & 2 & 1 & 1 & 0 \\
\hline Martín & 5 & 4 & 4 & 2 & 4 & 3 & 1 \\
\hline Lucía & 10 & 3 & 5 & 0 & 1 & 2 & 0 \\
\hline Ricardo & 6 & 4 & 11 & 1 & 2 & 1 & 0 \\
\hline Juan & 4 & 4 & 7 & 0 & 0 & 2 & 0 \\
\hline Raúl & 10 & 2 & 6 & 3 & 1 & 1 & 0 \\
\hline TOTAL & 58 & 26 & 53 & 15 & 13 & 13 & 3 \\
\hline
\end{tabular}

My case studies include six community gardeners (from Denison and Marshalltown) and two beginning vegetable farmers who had been gardeners in the past. ${ }^{4}$ This differentiation allows us to compare differences or similarities not only in the scale of farming and gardening, but also differences or similarities that may exist between these Latino and Latina immigrants who garden and farm through the lenses of different experiences, goals, and purposes. I recorded all eight interviews and used the software program NVivo to analyze them. I coded the transcriptions of the eight interviews by the following elements as mentioned by the participants: all the forms of community capital before and during the gardening and farming experience in 2009, the meanings of the gardens, types of crops they used in their countries and in their current gardens, specific agricultural knowledge, food preparation and preservation, demographic data, and barriers to and expectations about their future in farming and gardening in Iowa.

\section{Findings and Discussion}

The participants in this study reported indicators of buman, cultural, and social capital most frequently as

${ }^{4}$ Although the interviews were individual, sometimes I included husbands or wives as they were part of the team that participated in the same plot. The information from their partners was registered with field notes and informal conversations with them. In addition, I used pseudonyms for all of the participants to protect their confidentiality. prominent elements of their farming and gardening enterprises in these two rural Iowa towns (see table 2). Their agricultural knowledge and background, the cultural meanings that gardens hold for them, and the importance of sharing both food and experience were mentioned by all the interviewees as the main motives for their participation in growing vegetables, fruits, legumes, and herbs in their gardens.

\section{Human Capital: Agricultural Knowledge and Skills}

Key elements the participants mentioned included transmission of knowledge about gardening and farming to new generations, knowledge exchange with other gardeners and farmers, and the enhancement of financial and natural capital through education. The beginning farmers who participated in the course Start Your Own Diversified Farm mentioned these points more often than the community gardeners. In that course they learned about organic production and its attributes and market possibilities.

All the Latino gardeners and beginning farmers who participated in this study grew up on farms or ranchos in Mexico, Guatemala, or El Salvador.

Those farms combined production of livestock, grains, and some vegetables. All learned to cultivate diverse crops when they were between 6 and 14 . All the male gardeners helped their jefes (fathers) or their grandparents with preparing the soil for 
planting or cultivating. Farming knowledge gained at home and from their rural schools has remained with them, in part. Juan left Guatemala 33 years ago, but he still remembers how he learned to grow vegetables in his school with other students:

\section{En la escuela bacíamos grupos de a cuatro estudiantes para ver quien sacaba mayor cosecha al final....Sacábamos tomates, calabazas, y rábanos. Teniamos que ver que tenían los demás grupos pero nosotros teníamos muchos rábanos y con eso haciamos dinero que era mitad para la escuela y mitad para los cuates.}

In the school we formed groups of four students to see who could harvest the most....We picked tomatoes, squash, and radishes. We were always anxious to see how much the rest of the groups harvested, but we had lots of radishes, which we sold. Half of the money was for the school and half for the kids. -Juan

Most participants claimed that they learned about agriculture from their home countries and presumably retain that knowledge. However, they left their family farms many years ago and sometimes when they were very young. Thus, they talk about farming methods they used then that are not used in Iowa (like plowing with oxen in their home countries). Memory fades over time, so important details of farming practices learned in childhood may have been forgotten. In addition, latitude and weather are different in Iowa. What can be grown

Table 3. Vegetables, grains, legumes, herbs, and fruits cultivated by participants in their home countries and in their current gardens in lowa ${ }^{a}$

\begin{tabular}{|c|c|c|}
\hline Gardeners and origin & Crops grown in home country & Crops grown in their lowa gardens \\
\hline $\begin{array}{l}\text { Martín, Guanajuato, } \\
\text { Mexico }\end{array}$ & White corn, beans, tomatoes, peppers & $\begin{array}{l}\text { Cucumber, beans, onions, different kinds of } \\
\text { peppers, beets, green tomatoes, large red } \\
\text { tomatoes }\end{array}$ \\
\hline $\begin{array}{l}\text { Oscar and María, } \\
\text { Jalisco, Mexico }\end{array}$ & $\begin{array}{l}\text { Barley, alfalfa, wheat, pears, orange, lime, } \\
\text { different kinds of corn, potatoes, yams, beans }\end{array}$ & $\begin{array}{l}\text { “Poblano," jalapeño, Joe's Long Cayenne, and } \\
\text { yellow banana peppers, onions, yam bean } \\
\text { (lost), b four different kinds of squashes, } \\
\text { zucchini, five different kinds of tomatoes, } \\
\text { white corn (lost), cilantro, lettuces (lost), } \\
\text { cabbage (lost) }\end{array}$ \\
\hline $\begin{array}{l}\text { Lucía and Pedro, } \\
\text { Guachapán, El Salvador }\end{array}$ & Beans, white corn, tomatoes, chilies, rice & Beans, radish, tomatoes, squash \\
\hline $\begin{array}{l}\text { Pablo, Guanajuato, } \\
\text { Mexico }\end{array}$ & Tomatoes, peppers, white corn, peanuts & $\begin{array}{l}\text { Beans, peppers, green tomatoes, large red } \\
\text { tomatoes, cucumbers, white onions, sweet } \\
\text { potatoes }\end{array}$ \\
\hline $\begin{array}{l}\text { Guillermo and Silvia, } \\
\text { Michoacán, Mexico }\end{array}$ & White corn, wheat, beans, sorghum & $\begin{array}{l}\text { Two different kinds of tomatoes, cilantro, } \\
\text { chickpea, white corn, beans, watermelon, } \\
\text { squashes, belt (for first time), Santa Fe } \\
\text { Grande peppers }\end{array}$ \\
\hline $\begin{array}{l}\text { Ricardo, Campeche, } \\
\text { Mexico }\end{array}$ & $\begin{array}{l}\text { White corn, peppers, tomatoes, beans, } \\
\text { radish, cilantro }\end{array}$ & $\begin{array}{l}\text { Two kinds of tomatoes, onions, potatoes, } \\
\text { cucumbers, watermelons (lost) }\end{array}$ \\
\hline Raúl, Jalisco, Mexico & $\begin{array}{l}\text { White corn, beans, squash, cucumber, } \\
\text { sorghum, chickpeas }\end{array}$ & $\begin{array}{l}\text { Tomatoes, cucumber, Santa Fe Grande and } \\
\text { Joe's Long Cayenne pepper, cilantro, radish, } \\
\text { squash, onions }\end{array}$ \\
\hline $\begin{array}{l}\text { Juan, Municipio de } \\
\text { Quesada, Guatemala }\end{array}$ & White corn, beans & $\begin{array}{l}\text { Cabbage, cauliflower, onions, two kinds of } \\
\text { tomatoes, watermelon, melons }\end{array}$ \\
\hline
\end{tabular}

a Some of the crops are reported as gardeners named them because it was impossible to corroborate the scientific names.

$\mathrm{b}$ "Lost" means that that crop did not grow and died during that farming season. 
Table 4. Knowledge about different agricultural practices and skills, food processing, and places where gardeners and beginning farmers learned them

\begin{tabular}{|c|c|c|c|c|c|c|c|c|}
\hline $\begin{array}{l}\text { Types of practices } \\
\text { and/or skills }\end{array}$ & Martín & $\begin{array}{c}\text { Oscar \& } \\
\text { María }\end{array}$ & $\begin{array}{l}\text { Lucía \& } \\
\text { Pedro }\end{array}$ & Pablo & $\begin{array}{l}\text { Guillermo } \\
\text { \& Silvia }\end{array}$ & Ricardo & Raúl & Juan \\
\hline $\begin{array}{l}\text { Selecting and saving } \\
\text { seeds }\end{array}$ & $\begin{array}{l}\text { CA \& } \\
\text { MEX }\end{array}$ & MEX \& IA & SV & MEX \& IA & $C A \& I A$ & IA & MEX & GT \\
\hline $\begin{array}{l}\text { Planting and soil } \\
\text { preparation }\end{array}$ & $\begin{array}{l}\text { In previous } \\
\text { gardens, IA }\end{array}$ & $\begin{array}{l}\text { MEX, CA \& } \\
\text { IA }\end{array}$ & SV & $\begin{array}{l}\text { Television } \\
\text { U.S. }\end{array}$ & $\begin{array}{l}\text { MEX, CA \& } \\
\text { IA }\end{array}$ & MEX & $\begin{array}{l}\text { Sioux City, } \\
\text { IA }\end{array}$ & GT \\
\hline $\begin{array}{l}\text { Fertilizers, pesticides, } \\
\text { fungicides (natural } \\
\text { and artificial) }\end{array}$ & $\begin{array}{l}\text { In his } \\
\text { garden, } \\
\text { IA }\end{array}$ & $\begin{array}{l}\text { MEX } \\
\text { (natural) \& } \\
\text { IA } \\
\text { (artificial) }\end{array}$ & $\begin{array}{l}\text { In their } \\
\text { garden, IA }\end{array}$ & $\begin{array}{l}\text { MEX \& IA } \\
\text { (artificial) }\end{array}$ & $\begin{array}{l}\text { In their } \\
\text { garden, IA } \\
\text { (artificial) }\end{array}$ & $\begin{array}{l}\text { MEX } \\
\text { (natural); } \\
\text { IA } \\
\text { (artificial) }\end{array}$ & $\begin{array}{l}\text { Sioux City, } \\
\text { IA }\end{array}$ & $\begin{array}{l}\text { GT } \\
\text { (natural) \& } \\
\text { IA } \\
\text { (artificial) }\end{array}$ \\
\hline $\begin{array}{l}\text { Watering and } \\
\text { Irrigation }\end{array}$ & MEX & MEX & IA & MEX & MEX & MEX & MEX & GT \\
\hline $\begin{array}{l}\text { Equipment and tools } \\
\text { for farming }\end{array}$ & MEX \& IA & IA & SV & $\begin{array}{l}\text { MEX \& IA } \\
\text { garden }\end{array}$ & $\mathrm{CA}$ & MEX & MEX & GT \\
\hline $\begin{array}{l}\text { When and how to } \\
\text { harvest }\end{array}$ & $\begin{array}{l}\text { In his } \\
\text { garden, IA }\end{array}$ & MEX \& IA & SV & MEX \& IA & $\begin{array}{l}\text { MEX, CA \& } \\
\text { IA }\end{array}$ & MEX \& IA & MEX & GT \\
\hline $\begin{array}{l}\text { Marketing and/or } \\
\text { preserving food }\end{array}$ & $\begin{array}{l}\text { Drying } \\
\text { from MEX } \\
\text { \& other IA } \\
\text { gardeners }\end{array}$ & $\begin{array}{l}\text { Drying, } \\
\text { freezing, } \\
\text { canning, } \\
\text { marketing, } \\
\text { MEX \& IA }\end{array}$ & $\begin{array}{l}\text { Drying \& } \\
\text { canning } \\
\text { from } \\
\text { SV }\end{array}$ & $\begin{array}{l}\text { Drying \& } \\
\text { freezing } \\
\text { from IA } \\
\text { gardeners }\end{array}$ & $\begin{array}{l}\text { Drying \& } \\
\text { canning } \\
\text { from } \\
\text { friends \& } \\
\text { course in } \\
\text { MCC, IA }\end{array}$ & $\begin{array}{l}\text { Drying \& } \\
\text { freezing } \\
\text { from other } \\
\text { gardeners } \\
\text { in IA }\end{array}$ & $\begin{array}{l}\text { His wife: } \\
\text { Drying \& } \\
\text { canning, } \\
\text { MEX \& } \\
\text { other IA } \\
\text { gardeners }\end{array}$ & $\begin{array}{l}\text { Freezing } \\
\text { from GT }\end{array}$ \\
\hline
\end{tabular}

Abbreviations: California (CA), lowa (IA), Mexico (MEX), Guatemala (GT), El Salvador (SV).

and when it should be planted may be quite different from their experience in their home country. All eight participants validated their agricultural knowledge by explaining that somos del campo ("we are from the countryside"). However, a great part of the knowledge and skills learned about production of vegetables and fruits, particularly those crops selected for their gardens in Iowa, were not actually learned in their home countries at all (tables 3 and 4).

Many of the vegetables, legumes, herbs, and fruits that the participants grow in Iowa were neither grown in their countries nor known to them prior to their coming to the U.S. They learned about the types of crops they now grow through their own experiences or from observing other Latino gardeners in the U.S., particularly in Iowa. They also learned in Iowa about the care those different species and varieties require. Four of the eight participants migrated from their countries directly to California and worked on farms there. Three of the eight participants pointed out that they learned aspects of growing some varieties of vegetables and fruits in California, but that did not mean that they participated in the whole cycle of biological production. That learning experience only included specific agricultural tasks, which often were not directly related to horticulture.

Supplemented by the knowledge they brought from their countries and the experiences they gained from farm work in U.S, the great part of the participants' skills and knowledge about growing vegetables, herbs, and fruits were acquired from their experiences with home gardens (all of them in the towns where they live now and two also in places they lived before). 
All the participants were asked where they learned about the different practices and skills required by gardening and farming (see table 4). They learned most tasks from backyard gardening in the U.S., and from other Latino and Latina gardeners. ${ }^{5}$ Selecting, planting, and saving seeds are techniques learned in their home countries. However, many of the participants bought their plants from supermarkets or other stores. Some grew varieties from seed they knew from their home countries or from previous experiences. Four of the eight started seeds at home, in basements, in garages, or in the Marshalltown Community College greenhouse during the spring. Two also used improvised greenhouses at home. Germinating the seeds at home was learned in Iowa, since most came from countries and regions with less pronounced seasons in terms of temperature variation. Many of the gardening tasks required that they adapt their knowledge to seasonality and weather conditions in Iowa.

Many of the seeds that gardeners and beginning farmers used were obtained from friends or relatives, especially those that they could not easily get in local stores, such as white corn or particular varieties of pepper, tomato, and squash.

The most critical barriers the participants reported that they face as part of the gardening and farming process are a lack of access to manure or compost, knowledge of the nutrients needed by plants, knowledge about the control of pests, fungus, and insects, and knowledge about organic pesticides in particular. All the gardeners and beginning farmers knew about the application of natural fertilizers in their home countries. This knowledge sometimes came from an indigenous cultural heritage, as in the use of bat manure (guano). In Iowa they had to buy fertilizers and chemical pesticides in local stores and supermarkets. As they do not know much about those products, they asked other gardeners for advice. However, all the participants,

\footnotetext{
${ }^{5}$ This is with the exception of Juan, who mentioned that all the things he knew about gardening he had learned in Guatemala. His current community garden plot, however, represented his first year of gardening in the U.S. (see table 1).
}

especially the two beginning farmers, were aware of the benefits that natural and organic production can have not only for the environment, but also for their diets and health.

As Lawson (2005) points out, community gardens have historically been spaces with great educational possibilities. Knowledge exchange is also reflected in the plant varieties the participants select each year as a result of the advice and comments received from other gardeners and cooks. The exchange of varieties and recipes creates a rich multicultural environment where they try vegetables and recipes from other Latin American countries that were previously unknown to many of them. This knowledge exchange even overcomes the language barriers between Latino and Anglo gardeners. ${ }^{6}$ The gardens also allow the children of the gardeners and beginning farmers to learn about nature, agriculture, and related values.

For the two beginning farmers in the study, the Start Your Own Diversified Farm course helped them strengthen their knowledge about organic production, learn Iowa farming techniques from both professional instructors and farmers, acquire tools and practical experiences, experience bilingual instruction (Spanish and English), and interact with members of both Anglo and Latino communities. ${ }^{7}$

\section{Cultural Capital: Meanings of Farming and Gardening}

Among participants, cultural capital has an invisible role. It is embodied in their motivations, which are themselves rooted in their "agri-cultural" background. Among these gardeners and beginning farmers, cultural capital includes the meanings embedded in farming culture: sharing, the revalidation of life in the countryside, food identity, and the use of public spaces.

Growing for Latinos in Iowa revalidates life in the countryside and the cultural importance of being

\footnotetext{
${ }^{6}$ Notes from field work: conversation at the Denison community gardens with Doug, the only Anglo gardener, and Raúl. ${ }^{7}$ Notes from the field work during the Start Your Own Diversified Farm class, March 2009.
} 
outside and in contact with nature. Gardens and farms are spaces where Latinos who come from rural parts of their countries feel that they are not so far from the lands where they grew up, as they reconstruct natural environments with different varieties of fruits, vegetables, and herbs. Community gardens and the farm at the community college are more than recreational places and even more than the produce they generate; they are un pedacito del campo, a little piece of the countryside.

\section{Es algo que me gusta mucho, Diego. Es algo que no quisiera perderlo yo. Es como una tradición o como un pasatiempo. Porque nosotros traemos el monte y el campo en la sangre, yo creo, uno no lo puede dejar.}

It is something that I really like, Diego. It is something that I do not want to lose. It is like a tradition or like a hobby. Because we have the forest and the countryside in our blood, I think, I cannot get along without it. -Ricardo

Gardeners and farmers reconstruct not only the built and natural capital of their past, but also the meanings of gardening, farming, and being outside in a rural town in Iowa. These towns do not have many public spaces where people can go to relax, to be outside interacting with others, and so gardeners have created their own public spaces in the community gardens. That gardening experience is shared with relatives, friends, and people who enjoy the same things the gardeners enjoy.

When I asked about the importance of growing food for their lives, all eight mentioned that one of their main motivations was to share the produce with friends, relatives, and other people.

La papa la regalé toda a mis hermanos, Diego. A mi papá nunca le gustó vender las cosas. Mejor si va un amigo o pasa un amigo mejor. Se las regalas en México, él nunca anduvo vendiendo sandías. La gente que llegaba él les daba las sandías, quien sabe porque esa costumbre que tiene él, y a lo mejor es porque la tenemos nosotros, porque a mi no me

\begin{abstract}
gusta tampoco vender. Yo, si veo un amigo, se lo regalo.
\end{abstract}

I shared all the potatoes with my brothers, Diego. My dad never liked to sell things; for him it was better to give things as presents to friends. In Mexico, he never went around selling watermelons. When people came to visit, he gave them watermelons. Who knows why he had that habit? And more than likely that is why we share this value - I don't like to sell my produce, either. If I see a friend, I will give it away to him. $\quad$-Ricardo

Sharing is not only based on the participants' cultural backgrounds, but also on the social recognition they gain in the local community as someone who gives to others and works hard. Cultural capital is not only reinforced by the fact of sharing the experience and produce, but sharing also reinforces social and political capital. The cultural image of "I am still a campesino" (country person) builds both bonding and bridging capitals, and one gains social prestige with both the Latino and Anglo communities in these two rural towns. That is reflected in the positive feedback they receive from people who consume their homegrown produce. All eight gardeners and beginning farmers pointed out that recognition and appreciation of what they do generally is only valued by some people inside the Latino community, and not by many in the rest of the society. That contrasts with the comments from the people with whom they share their produce, who usually ask them to grow the same thing next year, or, amazed, ask where or how they grew that chili or tomatillo. Consequently, gardeners and farmers are proud of their work and their produce. That cultural and social recognition serves to motivate them to persist in gardening and farming. In addition, the image of gardening and farming transmits stability, health, and membership to the community.

Because farming and eating fresh food is an essential part of the Latino immigrant culture, the fact that they can have this experience in these rural 
towns enriches other capitals and consequently the whole society.

\section{Social Capital: Building Social Relationships Through Gardening and Farming}

Gardens and farming plots provide spaces for developing social relationships. Participants gather together with their families and friends, reinforcing bonding social capital by sharing the experience of gardening and farming and the products harvested. All eight participants learned of the community gardens and the land available at the incubator farm from relatives, friends, and other Latino and Latina gardeners. Gardening and farming are topics that reveal and reinforce common interests and motivations among Latino immigrants. All eight participants reported exchanging experiences about the previous year's growing season and sharing vegetable and fruit seeds along with recommendations about weather in Iowa, germination time, the care of different plants, and how to cook or preserve different vegetables after harvest.

During the farming season, gardens and the incubator farm became places where all members of the gardeners' families could come to help and/or to socialize and interact with relatives, friends, and other gardeners. In Denison, the community gardens acquire a special social meaning because they are located next to the soccer fields where a great of part of the Latino community goes every weekend during the summer. As Harvey (1973) points out, space plays a distinctive role in both the organization of production and the patterning of social interaction. The location of the community garden in Denison is of great importance, because people attending the soccer games can see and visit the gardens. The space is socially and culturally revitalized by everyday social practices.

In these two towns there is generally little interaction between the Latino and Anglo communities, creating two parallel worlds. However, the experience of the gardeners shows how interaction can be increased through agriculture and noncommercial food networks established between these two communities (bridging social capital). All the gardeners and one of the beginning farmers told me how they share vegetables and fruits with workmates, whether Latinos or Anglos.
Mira como esos chiles, yo me llevo bolsas para el trabajo y abi en el trabajo saco mis chiles y si hay gente que me dice ¿me das un chile?, yo les digo, y si hombre, agarra los que quieras. Si, a diario tengo mi bolsita con chiles, o mira esos tomatillos, vino mucha gente y se llevó...

See with chilies, I take bags of them to work and there I take out my chilies and if people ask me, "Will you give me one?" I say, "Sure, man, take what you want." Yes, every day I have my bag with my chilies or other produce. Look at those tomatillos! Many people came and took them... - Pablo

The gardeners and beginning farmers not only share their agricultural products with fellow workers, relatives, and friends, but also with institutions that support low-income families or poor people and churches. Lucía makes papusas (a traditional dish from El Salvador) in the local Baptist church. Most of the tomatoes and beans that she and her husband Pedro harvest from their small plot are used in the celebrations the church organizes to raise money for a new building. Thus the social networks established are transformed into collective financial capital through food.

However, social capital does not always reinforce financial capital. For example, there were classes about planting, combating pests, and how to sell in the farmers' market. In Denison those classes were bilingual and organized by Iowa State University Extension and the M\&M Divide RC\&D in Carroll. Although most of the participants had indicated interest in those classes, only a few attended, and none wanted to sell products in the local farmers' market. As Flora \& Flora (2008) point out, high bonding social capital combined with low bridging social capital reduces access to information and other resources from the outside. In these situations, groups do not trust each other and are reluctant to cooperate with one another (Flora \& Flora, 2008). The evaluation of the project "Scaling 
Up to Market: Building Capacity among Immigrant Community Gardens" in Denison Community Gardens found that the lack of trust diminished gardeners' access to education or marketing in the local farmers' market (Emery, Flora, \& Thompson, 2009). The combination of high bonding social capital and low bridging social capital also limited the individual aspirations of those gardeners who had previously indicated interest in selling at farmers' markets. However, there are other elements that may have influenced the interest in marketing the gardeners had shown at the beginning of that project: their social and cultural motivations for sharing rather than selling vegetables, the information available, the sizes of the plots, the small quantity of production, and time availability.

\section{Natural and Built Capitals}

In 2009 all eight participants rented land at affordable prices. Seven of the eight had gardens in Marshalltown or Denison before 2009. Before 2009 , six of the eight had home gardens in which they cultivated vegetables and herbs for everyday use, including cilantro, peppers, and tomatoes, among others. In addition, two of the eight rented small farming plots and cultivated land from other Latinos outside of town previous to 2009.

The two beginning farmers rented and cultivated land at a larger scale for the first time in 2009 at Marshalltown Community College. In previous years they had smaller backyard gardens at homes and/or on rented land.

From their gardening and farming experiences, seven of the eight voiced concern about the applications of chemicals to the soil they cultivated. These seven claimed that they preferred food without chemicals, and in three cases (including the two beginning farmers) highlighted the importance of soil quality and conservation. The two beginning farmers did not use artificial fertilizers, pesticides, or fungicides, because the land they used was being prepared for organic certification. The two community gardeners at the community college used artificial fertilizers, but they would have preferred to use natural products. The four gardeners in
Denison used artificial fertilizers and pesticides in their plots. However, all claimed that they knew about (from their experiences in their home countries), and would have preferred to use, natural products like manure that are not easily acquired in small quantities in these towns.

\section{Financial Capital}

The two beginning farmers got started in largerscale vegetable growing with a relatively small cash investment ( $\$ 500$ and $\$ 3,000$ ). Those expenses included seeds, tools, and transportation to market. Neither of the farmers achieved a net profit, but each estimated having reduced food expenditures by about $\$ 700$ annually per household by growing some food for his or her own household.

Economic factors (financial capital) did not represent an important motivation among seven of the eight participants. Profit was important for only one of the beginning farmers, but even for him financial gain did not represent the most important motivation for farming.

\section{En nuestra mente no pensamos que nos vamos a hacer ricos de la agricultura pero si pensamos que la gente come más saludable y que es muy lindo trabajar afuera y mirar recoger nuestros productos.}

In our minds we do not think that we are going to become rich from farming, but we think that people eat healthier and that it is very nice to work outside and see our products being harvested. -Oscar

Oscar and his wife María sold vegetables in the Des Moines Farmers' Market and made a few sales to stores in Marshalltown and Ames, Iowa. They were aware that they could not earn enough that first year to turn a profit, but they are trying to increase their farm sales and profits based on what they learned in 2009. Even though Oscar knows that he needs to generate profits, that is not his main motivation for participation in the beginningfarming program. His dream is to live and farm in the countryside, share produce, and be self-reliant by producing food for his family, and only later to make some money. 
Guillermo and his wife Silvia, the other beginningfarmer household, did not want to sell their products in 2009; they preferred to consume and also to share them. However, because they learned from the Start Your Own Diversified Farm course and from the experience of other Latino beginning farmers that marketing their crops could be a viable option, they are analyzing the possibility of selling some of their produce in the future.

For all the participants, the primary return on investment was the high-quality and healthy food they obtained from their plots. They raised enough vegetables for their families and even for friends and relatives. All felt that their gardens were very important not only for their domestic budgets, but also for the quality of their diets.

\section{Political Capital}

Political capital is still low among participants of organized gardening and farming activities in these two towns. However, participation in educational programs may represent opportunities for Latino representation and active participation in issues regarding the whole community.

\section{Summary of Findings}

The community capitals reported by participants interact with and strengthen one another. Human capital based on cultural capital strengthens social capital, which is one of the most critical elements among Latino and Latina gardeners and beginning farmers. Social capital not only motivates gardeners and beginning farmers to cultivate, but also to build bridging and bonding social capital (through sharing the experiences and produce) in these towns, establishing new and stronger relationships within and outside the Latino community. That encourages more egalitarian cross-cultural contact and enhances the exchange of cultural knowledge between Anglos and Latinos.

Among the participants of this study, cultural capital is one of the most important motivations for gardening and farming. Cultural capital has a special meaning rooted in cultural tradition; it reinforces identity as a "countryperson" (campesino). That identity leads to new social relationships, which are reinforced by sharing the produce and experiences with gardening, food, and outdoor living with family and friends.

Latino and Latina gardeners and beginning farmers enhanced their access to natural and built capitals by mobilizing social, cultural, and buman capitals.

Financial gain (acquiring financial capital) was not the primary motivation for participation in the projects. However, gardeners and beginning farmers save money by not purchasing vegetables, fruits, legumes, and herbs that they grow themselves.

Educational programs designed for both Anglos and Latinos (buman and social capitals) like Start Your Own Diversified Farm facilitate cultural exchange about agricultural techniques and meanings (cultural capital). The participants in the course for beginning farmers at Marshalltown Community College expanded their social networks. They mentioned the importance of establishing new relationships with both Latinos and Anglos (bridging social capital). The construction of new social networks allowed access to certified organic land (natural capital), markets (financial capital), infrastructure for farming (built capital), education and knowledge about gardening (buman capital), and more active participation in community institutions (political capital). As Emery points out, the outcomes "are not only better food and access to foods for Latino/ immigrant populations, but also increased trust and communication across language and cultural divides" (Emery, 2010, p. 29). The Latinos and the Anglos learned they shared values around the importance of fresh food, the meaning of being a gardener or farmer, and eventually the importance of being an agricultural entrepreneur. They also shared particular skills related to cooking and preserving their produce.

The participants have an agricultural background and knowledge (buman capital) from both their home countries and from other parts of the U.S. that have enriched their gardening and farming experiences. That knowledge of gardening and farming is important in transmitting food and 
farming knowledge to others and in the strengthening of other community capitals.

Political capital is a critical capital that needs to be developed so they can secure stable locations for gardening and farming, have more representation in related projects, and reinforce new channels of social and cultural integration through food and agriculture. This represents a challenge for the future of sustainable gardening and farming projects in rural towns or metropolitan areas with immigrant newcomers in the U.S. This may be difficult, however, as long as the immigration system makes it dangerous to call attention to oneself through organizing.

\section{Conclusions}

Human, cultural, and social capitals are the capitals that most benefited this study's participants. All three capitals facilitate access to other capitals. These interviews suggest that although Latino immigrants bring experience in diversified agriculture and an appreciation of local, fresh food to their gardening or farming, they need assistance focused on horticultural and agricultural production practices that are specific to the geographical and geological context of the region in which they currently live. Strengthening of human capital through the use of appropriate educational tools for this population can improve their gardening or farming success considerably, because in this country they find many natural, economic, and cultural challenges that need to be solved with new knowledge and new skills. Bilingual courses for Latino or other immigrant gardeners or beginning farmers clearly offer opportunities not only in terms of knowledge of production and sustainable practices, but also in social networking and financial opportunities. However, those courses and incubator programs need to incorporate creative elements for including Latinos and Latinas, establishing social networks based on trust and reciprocity that link them to the community and local institutions.

Both classrooms and gardens provide venues to share advice and support for healthier agricultural practices, appreciation for fresh and organic products and practices, and channels to access natural capital such as high-quality natural fertilizers or pesticides. Human capital enhanced by education can facilitate access to financial opportunities, such as selling and marketing their produce - for those who desire to do so.

Enterprises need to be based on the cultural meanings that gardening and farming have for the Latino community. The reciprocity that sharing entails enhances knowledge exchange, commitment, trust, and cultural integration. For example, Latino immigrants' focus on giving away rather than selling their produce is in sharp contrast to the focus on selling and profit of those offering the training. The validity of sharing as an end in itself must be recognized if Anglo institutions are organizing the courses. This can happen if Latinos and Latinas are offered the chance to actively participate in designing and implementing the curriculum.

The spiral diagram in figure 2 (next page) illustrates the importance of human capital and how these capitals are connected and can be strengthened for sustainable projects or enterprises that include Latinos and Latinas in agricultural and local food systems efforts.

Future studies should explore critical aspects of political capital and the interactions between the institutions that organize and support Latino and Latina gardeners and beginning farmers and the participants themselves. That will provide more insight about how integration can be achieved in both rural towns and in urban areas of the U.S., through sustainable "agri-cultures" and high quality food.

\section{Acknowledgments}

Thanks to all the gardeners and beginning farmers and their families who directly or indirectly participated in this study, to my fellow graduate students at Iowa State University (ISU) who provided me materials and information, and to Dr. Jan Flora, Dr. Cornelia Flora, Dr. Gail Nonnecke, and Mr. Richard Pirog of ISU for reviewing this study throughout its entire process. 


\section{Figure 2. Spiraling-Up: Agricultural knowledge and strengthening of the community capitals \\ (Modified from Gutierrez-Montes, 2005, and Emery \& Flora, 2006; Emery, Flora, \& Thompson, 2009)}
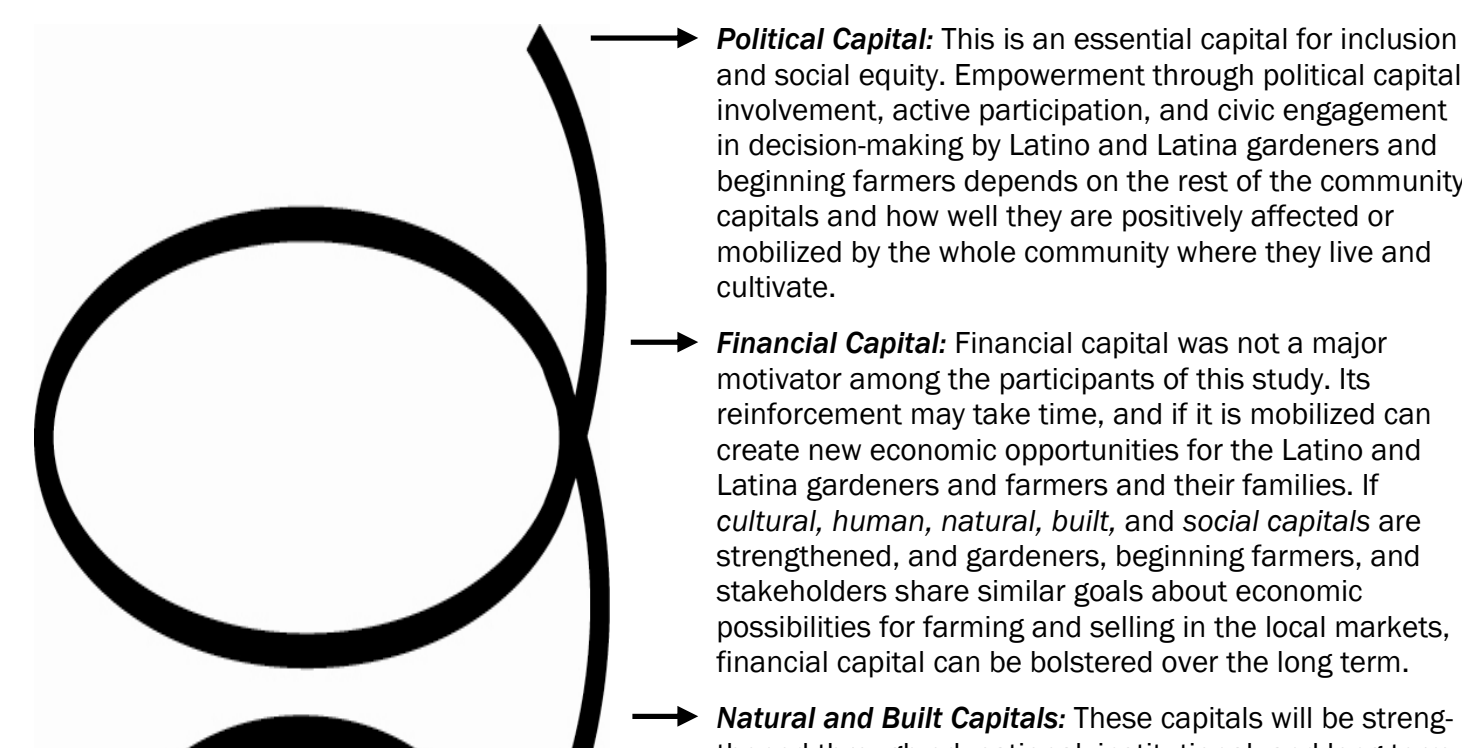
thened through educational, institutional, and long-term community support. This study shows that Latino and Latina gardeners and beginning farmers know about natural fertilizers, but they need improved access to them in lowa. They also need spaces for social recreation, good quality land, infrastructure, equipment, and other natural agricultural inputs.

Social Capital: Encouraged by farming and gardening experiences and learning, and by cultural meanings of growing and sharing food, social networking facilitates community integration. Sharing produce and gardening and farming experiences can not only overcome cultural barriers and allow access to healthy food and agricultural knowledge exchange, but also lead to social integration and justice.

Cultural Capital: Cultural comprehension is a key element in sustainable agriculture and local food systems efforts focused on the inclusion of Latino communities. It can be mobilized through social relationships and a spirit of commitment and mutual collaboration among the different communities involved. The cultural meanings that Latino and Latina immigrants have around identity as country people, around particular foods, and around the sharing of those foods can enrich the current agriculture and food systems in the U.S.

Human Capital: Latino and Latina gardeners and beginning farmers have important agricultural experiences from both their home countries and from other parts of the U.S. That knowledge needs to be strengthened through external resources and educational instruction about how to practice agriculture in regions like lowa. Gardening and farming have an important role in transmitting agricultural and food knowledge and in the mobilization of other community capitals as well.

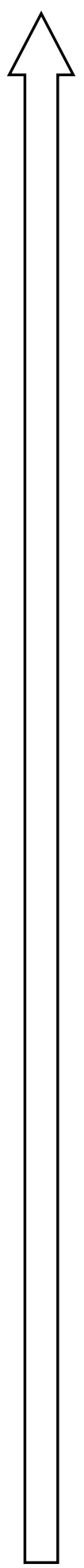




\section{References}

Allen, P. (2008). Mining for justice in the food system: Perceptions, practices, and possibilities. Agriculture and Human Values 25, 157-161. doi:10.1007/s10460-008-9120-6

Bourdieu, P., \& Passeron, J. C. (1977). Reproduction in education, society, and culture. London: SAGE Publications.

Bourdieu, P. (1986). The forms of capital. In J. G. Richardson (Ed.), Handbook of theory and research for the sociology of education (pp. 241-258). New York: Greenwood Press.

Denzin, N. (1970). Sociological methods: A sourcebook. Chicago: Aldine Publishing Company.

Denzin, N. (1989). The research act: A theoretical introduction to sociological methods. Englewood Cliffs, New Jersey: Prentice Hall.

Díaz, E., \& Guzman, B. (2002, April). The Hispanic population: 1990-2000 growth and change. Population Research and Policy Review, 21, 109-128. doi:10.1023/A:1016541906218

Emery, M. \& Flora, C. (2006, Spring). Spiraling-up: Mapping community transformation with Community Capitals Framework. Community Development: Journal of the Community Development Society, 37, 19-35. doi:10.1080/15575330609490152

Emery, M., Flora, J., \& Thompson, D. (2009). Scaling up to market: Building capacity among immigrant community gardens. Unpublished manuscript, evaluation report for National Immigrant Farming Initiative. Ames, Iowa: Iowa State University.

Emery, M. (2010). Latino farmers and local multicultural food and marketing systems. Unpublished manuscript, evaluation report for Leopold Center for Sustainable Agriculture. Ames, Iowa: Iowa State University.

Fink, E. (1998). Cutting into the meatpacking line: Workers and change in the rural Midwest. Chapel Hill, North Carolina: University of North Carolina Press.

Flora, C. \& Flora, J. L. (2008). Rural communities: Legacy and change. (Third ed.). Boulder, CO: Westview Press.

Glover, T. D. (2004). Social capital in the lived experiences of community gardens. Leisure Sciences, 26, 143-162. doi:10.1080/01490400490432064

Gutierrez-Montes, I. A. (2005). Healthy communities equal healthy ecosystems? Evolution (and breakdown) of a participatory ecological research project towards a community natural resources management process, San Miguel Chimalapa
(Mexico). (Doctoral dissertation, Iowa State University: Ames, Iowa). Retrieved from Dissertation Abstracts International. (3200422)

Guzmán, B. (2001). The Hispanic population: Census 2000 brief. United States Census Bureau. Retrieved from http://www.census.gov/prod/2001pubs/ c2kbr01-3.pdf

Harvey, D. (1973). Social justice in the city. London: Edward Arnold Editions.

Hou, J., Johnson, J. M., \& Lawson, L. J. (2009). Greening cities, growing communities: Learning from Seattle's urban community gardens. Seattle: University of Washington Press.

Kransy, M. \& Saldivar-Tanaka, L. (2004). Culturing community development, neighborhood open space, and civic agriculture: The case of Latino community gardens in New York. Agriculture and Human Values 21, 399-412. doi:10.1023/B:AHUM.0000047207.57128.a5

Lawson, J. (2005). City bountiful: A century of community gardening in America. Berkeley: University of California Press.

Lewis, H. K. (2007). Hacia el ranchito: Mexican immigrants, farming and sustainable rural livelihoods in Iowa. (Unpublished master's thesis). Iowa State University: Ames, Iowa.

Lewis, K. H. \& Tafoya, R. (2008). Assessing needs and fostering agricultural entrepreneurship among immigrants in Iowa. Unpublished manuscript, report for the Leopold Center for Sustainable Agriculture. Ames, Iowa: Iowa State University.

Lyson, T. A. (2004). Civic agriculture: Reconnecting farm, food and community. Lebanon, New Hampshire: Tufts University Press.

Neuman, W. L. (2003). Social research methods. Quantitative and qualitative approaches. Boston: Allyn and Bacon Editions.

Tienda, M., \& Raijman, R. (2000). Immigrants' incomes packing and invisible labor force activity. Social Science Quarterly, 81, 291-310.

U.S. Census Bureau. (2009). United States population projections: 2000 to 2050. Retrieved from http://www.census.gov/population/www/ projections/analytical-document09.pdf

Winne, M. (2008). Closing the food gap: Resetting the table in the land of plenty. Boston: Beacon Press. 